Irena Szczepankowska

Uniwersytet w Białymstoku, Polska

ORCID: 0000-0003-1056-606X

Ewa Gorlewska

Uniwersytet w Białymstoku, Polska

ORCID: 0000-0003-1513-0601

\title{
SPRAWIEDLIWOŚĆ W POLSKIM DYSKURSIE KONSTYTUCYJNYM I JEJ KONOTACJE SPOLECZNE
}

\section{WPROWADZENIE}

Na temat kształtowania się samego pojęcia sprawiedliwość oraz jego rozumienia na gruncie etyki, aksjologii, prawa i innych nauk społecznych napisano tak wiele od starożytności po czasy współczesne, że nasze obserwacje i płynące z nich wnioski mogą być jedynie skromnym lingwistycznym uzupełnieniem interdyscyplinarnej refleksji nad funkcjonowaniem tego pojęcia w kluczowych dla przestrzeni komunikacyjnej dyskursach społecznych. Chcemy zwłaszcza przyjrzeć się uobecnianiu idei sprawiedliwości w tekstach polskich konstytucji, zaczynając od Ustawy Trzeciomajowej z 1791 roku, a kończąc na traktowanej ze szczególną wnikliwością najnowszej Konstytucji Rzeczypospolitej Polskiej uchwalonej w 1997 roku. Znaczenia tekstowe nazw desygnujących przywołaną wartość oraz profile aktualizowane w kontekście prawodawczym zostaną skonfrontowane $\mathrm{z}$ konotacjami pojawiającymi się w wypowiedziach młodych Polaków: bierzemy pod uwagę obserwacje wyrażone w ankietach wypełnionych przez studentów białostockich uczelni.

Warto najpierw podkreślić charakterystyczne cechy Konstytucji jako tekstu-komunikatu, ponieważ pozwoli to na głębsze zrozumienie sprawiedliwości 
jako chronionego w niej dobra. Katalog wartości ujawniony w dokumencie tego rodzaju nie jest zbiorem przypadkowym, lecz sformułowanym przez określonego nadawcę - twórcę prawa mającego na uwadze dobro państwa i obywateli, a także konieczność wdrożenia norm prawnych i moralnych. Ma także odpowiednio sprofilowanego odbiorcę - nie jest nim osoba indywidualna, lecz obywatel państwa, członek społeczeństwa, który zyskuje pewne prawa (wolności) i obowiązki wobec współobywateli, władz i kraju. Dodatkowo funkcja perswazyjna Konstytucji, zwłaszcza jej preambuły, prowadzi do zaakceptowania i przyjęcia przez odbiorców prezentowanej im państwowej wizji świata wraz z tworzącymi ją wartościami, wśród których sprawiedliwość zajmuje wysokie miejsce.

\section{SPRAWIEDLIWOŚĆ W HISTORYCZNYM POLSKIM DYSKURSIE KONSTYTUCYJNYM}

Idea sprawiedliwości jest ściśle związana z pojęciem samego prawa: w języku polskim, podobnie jak u innych Słowian, słowa prawy, prawo, prawda, sprawa, sprawiedliwy i pochodne nomen abstractum sprawiedliwość ${ }^{1}$ są spokrewnione (por. też łac. ius, iustus, iustitia), a zasady prawa w wykładni rzymskiego prawnika Ulpianusa: Iuris praecepta sunt haec: honeste vivere, alterum non laedere, suum cuique tribuere (tj. żyć uczciwie, innego nie krzywdzić, przyznać każdemu, co jego jest) $)^{2}$ zostały zarazem uznane za kwintesencję sprawiedliwości. Do takiego rozumienia wartości nawiązują już w XVI wieku polscy prawnicy, np. Paweł Szczerbic, który tłumaczył na polski niemieckie prawa miejskie. Objaśnienie Szczerbica przytacza Samuel Bogumił Linde w swoim słowniku: Sprawiedliwość jest stateczny, nieodmienny, a prawie wieczny umyst każdemu to, do czego prawo ma, oddawaćs ${ }^{3}$. Choć proponowana eksplikacja odpowiada uniwersalizacji idei sprawiedliwości jako nadrzędnej wartości prawa, wypływającej z rozstrzygnięcia tego, co się komu stusznie należy, to trzeba od razu podkreślić, że w kolejnych epokach i przestrzeniach kulturowych praktyczna realizacja tej idei podlegała wymogom dominującego światopoglądu i ustroju politycznego. Można było zatem godzić pojęcie sprawiedliwości z porządkiem feudalnym, odnosząc je

${ }^{1}$ Przymiotnik sprawiedliwy został zapożyczony w XV wieku z języka czeskiego (spravedlivý, stcz. spravedlný) do polszczyzny, skąd z kolei przejęli go wschodni Słowianie (por. ros. spravedli$v y j$ ), a stamtąd słowo to trafiło także do języków południowosłowiańskich (zob. W. Boryś, Stownik etymologiczny języka polskiego, Kraków 2005).

${ }^{2}$ Cytat łac. za: W. Litewski, Stownik encyklopedyczny prawa rzymskiego, Kraków 1998, s. 135.

${ }^{3}$ S. B. Linde, Słownik języka polskiego, t. 1-7, Lwów 1854. 
do równouprawnienia wewnątrzstanowego, różnego dla poszczególnych warstw społecznych ${ }^{4}$.

Samo słowo sprawiedliwość, choć poświadczone w pismach politycznych od XV wieku w znaczeniach „uczciwość, prawość”, „zgodność z przepisami prawnymi”, „bezstronność”, „prawda, słuszność, rzetelność”, rzadko pojawia się $\mathrm{w}$ tekstach prawodawczych, których przedmiotem jest stanowienie norm postępowania. Abstrakcyjna nazwa wartości jest natomiast wymieniana w konstytucjach, zwłaszcza w preambułach, których przeznaczeniem jest ujęcie fundamentalnych wartości, na jakich opiera się stanowione prawo.

W preambule Ustawy Rządowej z dnia 3 maja 1791 roku $^{5}$ sprawiedliwość nie jest jednak wskazywana, gdyż obronie uwarunkowanej potrzebą chwili, co ustawodawcy wyraźnie deklarują, podlegały wartości szczególnie wówczas zagrożone: niepodległość zewnętrzna i wolność wewnętrzna narodu. Natomiast w artykule II wartość tę aktualizuje słowo sprawiedliwie użyte w kontekście nadanych szlachcie praw i przywilejów. Kolekcja sprawiedliwie i prawnie nadane konotuje „słuszność" jako kryterium oceny moralnej i politycznej aktu nadania uprawnień, podczas gdy przysłówek prawnie oznacza raczej sformalizowany, zgodny z przepisami sposób realizacji aktu. Określenie adiektywne sprawiedliwy pojawia się także w Konstytucji 3 Maja w kanonicznym kontekście realizowania sprawiedliwości w rozumieniu prawnym, tj. wydawania wyroku polegającego na wyznaczaniu kary i nakazywaniu zadośćuczynienia za krzywdę: w sytuacji, gdy obwinieni o przestępstwa urzędnicy mają być kierowani do sądów sejmowych: po sprawiedliwe $i$ wyrównające przestepstwu ich ukaranie, lub przy dowiedzionej niewinności, od sprawy i kary uwolnienie (art. VII). Nazwa abstrakcyjna jest dwukrotnie powtórzona w artykule VIII Ustawy Trzeciomajowej poświęconym władzy sądowniczej:

Władza sądownicza (...) Powinna być zaś tak do miejsc przywiązaną, żeby każdy człowiek bliską dla siebie nalazł sprawiedliwość, żeby przestępny widział wszędzie groźną nad sobą rękę krajowego rządu. (...) Sądy pierwszej instancyi będą zawsze gotowe i czuwające na oddanie sprawiedliwości tym, którzy jej potrzebują.

Kontekst użycia rzeczownika i pochodnych określeń atrybutywnych w Konstytucji 3 Maja wyraźnie zatem wskazuje na prawny, a ściślej mówiąc sądowy, aspekt sprawiedliwości pojmowanej jako słuszność ustawy i wyroków sądowych, wyznaczających uprawnienia i obowiązki, nagrody i kary.

Ze sprawiedliwością można także skojarzyć podkreśloną w artykule II równość wewnątrz stanu szlacheckiego:

${ }^{4}$ Zob. więcej na ten temat: I. Szczepankowska, Prawo $i$ wolność $w$ dyskursie politycznym Rzeczypospolitej przedrozbiorowej (podstawowe problemy badawcze), „Poradnik Językowy” 2008, nr 8, s. 75-93.

${ }^{5}$ Cyt. za wydaniem: Konstytucja 3 Maja 1791. Statut Zgromadzenia Przyjaciół Konstytucji, oprac. J. Kowecki, Warszawa 1991. 
Wszystką szlachtę równemi być między sobą uznajemy, nie tylko co do starania się o urzędy i o sprawowanie posług ojczyźnie, honor, sławę i pożytek przynoszących; ale oraz co do równego używania przywilejów i prerogatyw stanowi szlacheckiemu służących.

Dodajmy, że równość, którą można uważać za podstawowy profil znaczeniowy pojęcia sprawiedliwości, jest naczelnym postulatem proklamowanej nieco wcześniej (w 1789 roku) francuskiej Deklaracji Praw Człowieka i Obywatela, lecz égalité rozumiano jako równouprawnienie wszystkich ludzi niezależnie od jakichkolwiek różnic społecznych, ekonomicznych, światopoglądowych i innych. Z kolei w poprzedzającej francuską Deklarację Konstytucji Stanów Zjednoczonych Ameryki (akt uchwalony w 1787 roku) - w krótkiej preambule deklarującej cele prawodawcy - znalazło się umocnienie sprawiedliwości (establish Justice), a kontekst aksjologiczny, w jakim nazwa wartości się pojawia (wzmocnienie federacji, zagwarantowanie pokoju wewnętrznego), pozwala sądzić, że sprawiedliwość mieści się w polu semantycznym „bezpieczeństwa”, a więc desygnowana wartość jest traktowana jako warunek spokoju społecznego, który jest zapewniony wówczas, gdy obywatele nie muszą walczyć z niesprawiedliwością ${ }^{6}$.

W pierwszej konstytucji II Rzeczypospolitej Polskiej (pomijamy tu XIX-wieczne akty oktrojowane), czyli w preambule ustawy z dnia 17 marca 1921 roku $u^{7}$ uwypuklono obronę świeżo odzyskanej wolności i postulat zjednoczenia Polaków; w katalogu najważniejszych symboli nie ma hasła sprawiedliwość, ale można uznać, że podkreślono szczególny (społeczny) profil wartości, tj. równość zapewnianą wszystkim obywatelom Rzeczypospolitej i konkretyzowaną w kilku artykułach ustawy, w tym w art. 96, gdzie stwierdzono: Wszyscy obywatele sa równi wobec prawa. W tekście aktu słowo sprawiedliwość występuje głównie w wyrażeniu wymiar sprawiedliwości, użytym raz w znaczeniu podmiotowym „,instancje sądowe” (art. 2) oraz dwa razy w znaczeniu orzeczeniowym „wymierzanie sprawiedliwości” (art. 21, 74). Jako nazwa jednej z najważniejszych wartości pojawia się natomiast ten rzeczownik w kontekście roty przysięgi przepisanej w art. 54 dla Prezydenta Rzeczypospolitej, a więc reprezentanta władzy wykonawczej, który przyrzeka stać na straży dóbr konstytucyjnych i między innymi sprawiedliwość względem wszystkich bez różnicy obywateli za pierwsza sobie mieć cnotę. Kontekst modeluje tutaj rozumienie sprawiedliwości w kategoriach traktowania obywateli jako równouprawnych podmiotów.

${ }^{6}$ Zob. na ten temat: I. Szczepankowska, Zwiąki polskiego, amerykańskiego i francuskiego dyskursu konstytucyjnego w XVIII wieku, (w:) Dyskurs prawny. Języki, teksty i konteksty, Białystok 2016, s. 101-120.

${ }^{7}$ Ustawa z dnia 17 marca 1921 r. - Konstytucja Rzeczypospolitej Polskiej, Dz.U. nr 44, poz. 267. 
Konstytucja Polskiej Rzeczypospolitej Ludowej z 1952 roku ${ }^{8}$ umacniała podstawy ustroju politycznego, zwanego też ustrojem sprawiedliwości społecz$n e j$ - koncept ten był sednem socjalistycznego etosu, który miał się realizować w dawaniu każdemu wedtug potrzeb. Takie sformułowanie nie pada jednak w Konstytucji, która w art. 14 ust. 3 parafrazuje rzymską zasadę w bardziej realistyczny sposób: od każdego wedlug jego zdolności, każdemu wedtug jego pracy. W świetle stereotypowego obrazu zasad ustrojowych PRL-u preambuła najważniejszego aktu prawnego - bardzo rozbudowana i wymieniająca szeroki katalog dóbr w propagandowo wystylizowanej ramie modalnej - może zaskakiwać przez to, że nie uwypukla sprawiedliwości, choć tak jak w wypadku innych podobnych aktów prawnych, można dopatrzyć się implikowania tej wartości w treści wielu postulatów, np.: [walka z] zaciektym oporem rozbitków starego ustroju kapitalistyczno-obszarniczego czy [walka o] dalsze polepszenie stosunków społecznych, o całkowite zniesienie wyzysku człowieka przez człowieka, o urzeczywistnienie wielkich idei socjalizmu. Samo słowo sprawiedliwość ani nawet nazwa równość (desygnująca wartość konkretyzowaną w wielu artykułach Konstytucji) jednak nie padają w preambule, a podstawowy przymiotnik użyty jest w dość niekonwencjonalnym kontekście, choć zrozumiałym na tle ówczesnych realiów geopolitycznych, gdyż wzmiankuje się o nowych, sprawiedliwych granicach, tj. „granicach słusznie (sprawiedliwie) wytyczonych”. Użycie kolokacji, podobnie jak wielu innych sformułowań w preambule, ma wyraźnie na celu swego rodzaju zaklinanie rzeczywistości, czyli wyrażenie bezwarunkowej aprobaty dla kontrowersyjnych w istocie decyzji politycznych w kontekście ustanawiania nowego powojennego podziału terytorialnego. Poza tym jednak rzeczownik sprawiedliwość pojawia się jako standardowe dopełnienie kategorii werbalnej w wyrażeniu wymiar sprawiedliwości konotującym sądy (art. 46). Na pewien szczególny aspekt interpretacji omawianej wartości zwraca uwagę sformułowanie w art. 74 ust. 2:

Skargi i zażalenia obywateli powinny być rozpatrywane i załatwiane szybko i sprawiedliwie. Winni przewlekania albo przejawiający bezduszny i biurokratyczny stosunek do skarg i zażaleń obywateli pociągani będą do odpowiedzialności.

Można wnioskować z kontekstu użycia określenia, że sprawiedliwe rozpatrywanie skarg oznacza według prawodawcy nie tyle kierowanie się sędziów literą prawa, ile duchem zrozumienia dla petentów, współodczuwaniem i chęcią pomocy.

\footnotetext{
${ }^{8}$ Konstytucja Polskiej Rzeczypospolitej Ludowej z dnia 22 lipca 1952 r., Dz.U. nr 33, poz. 232.
} 


\section{SPRAWIEDLIWOŚĆ W ŚWIETLE AKTUALNEJ POLSKIEJ USTAWY ZASADNICZEJ}

Sprawiedliwość jest jedną z najważniejszych kategorii aksjologicznych pojawiających się w aktualnej polskiej Konstytucji ${ }^{9}$. Zajmuje w niej szczególne miejsce, ustawodawca sytuuje ją bowiem wśród wartości uniwersalnych, a więc wspólnych wszystkim ludziom, istotnych bez względu na partykularne, często skrajnie różniące się, stanowiska światopoglądowe. Pojęcie to jest także głównym wyznacznikiem etycznego porządku, ten zaś stanowi warunek spójności tożsamościowej narodu i więzi opartej na poszanowaniu tych samych podstawowych wartości ${ }^{10}$. Poszczególne profile pojęcia sprawiedliwość, ukryte w połączeniach z leksemami konkretyzującymi jego konstytucyjny sens oraz w kolekcjach wyrazowych, odzwierciedlają interpretację świata swoistą dla analizowanego aktu prawnego.

Nazwa sprawiedliwość jest wyrazem prymarnie wartościującym - to znaczy, że zawiera definicyjny składnik wartościujący odnoszący się do treści wyrazu ${ }^{11}$, którego sens wiąże się z takimi nacechowanymi aksjologicznie znaczeniami, jak „zgodny z prawem”, „właściwy”, „dobry”. Desygnuje nie tylko określony stan w rzeczywistości prawnej i społecznej, lecz także (w nie mniejszym stopniu) pewne aksjologiczne dobro. W tekście aktualnej ustawy zasadniczej pojawia się już w początkowych słowach preambuły:

W trosce o byt i przyszłość Naszej Ojczyzny, odzyskawszy w 1989 roku możliwość suwerennego stanowienia o Jej losie, my, Naród Polski - wszyscy obywatele Rzeczypospolitej zarówno wierzący w Boga będącego źródłem prawdy, sprawiedliwości, dobra i piękna, jak i niepodzielający tej wiary, a te uniwersalne wartości czerpiący z innych źródeł (...) ${ }^{12}$.

Usytuowanie sprawiedliwości w najważniejszym pod względem ideologicznym miejscu Konstytucji podkreśla szczególną wagę desygnowanego dobra wśród innych fundamentalnych wartości. W myśl preambuły sprawiedliwość uzupełnia klasyczną Platońską triadę wartości mieszczącą prawdę, dobro i piękno - kategorie aksjologiczne leżące u podstaw europejskiego kanonu wartości. Występowanie w kolekcji z tymi wartościami podnosi rangę sprawiedliwości jako dobra najwyższego, dającego początek innym wartościom, wyznaczającego kierunek aksjologiczny polskiej kultury. Należy podkreślić, że dobra chronione w ustawie

${ }^{9}$ Zob. Konstytucja Rzeczypospolitej Polskiej z dnia 2 kwietnia 1997 r., Dz.U. nr 78, poz. 483, z późn. zm.

${ }^{10}$ Zob. Z. Stawrowski, Aksjologiczne podstawy Konstytucji, Rzecznik Praw Obywatelskich, http://www.rpo.gov.pl/pliki/12180269390.pdf (dostęp: 3.02.2019 r.).

${ }^{11}$ Zob. J. Puzynina, Język wartości, Warszawa 1992, s. 120.

${ }^{12}$ Konstytucja Rzeczypospolitej Polskiej z dnia 2 kwietnia 1997 r. ... 
zasadniczej są dla narodu wartościami kanonicznymi ${ }^{13}$. Preambuła zaś wyraża aksjologie danej konstytucji, jej podstawy światopogladowe i przyjęty system wartośc $i^{14}$. Sprawiedliwość została włączona przez ustrojodawcę do grupy dóbr ogólnoludzkich również ze względu na jej związek z prawem - jednym z filarów funkcjonowania państwa jako struktury politycznej. Jest ona wszak podstawowa zasada $i$ wartościa państwa prawa ${ }^{15}$. Modyfikacja klasycznej trójcy wartości jest więc związana z państwowym obrazem świata prezentowanym na kartach ustawy zasadniczej, odzwierciedlonym między innymi w doborze chronionych dóbr. Świat ten jest przestrzenią norm, praw i relacji, w nim zaś sprawiedliwości przypada rola wyznaczania granicy między tym, co właściwe, a tym, co naganne.

W ujęciu współczesnego prawodawcy sprawiedliwość jest podstawową wartością i elementarnym prawem, na niej opiera się demokratyczny ustrój III Rzeczypospolitej ${ }^{16}$. Oto fragment preambuły:

(...) ustanawiamy Konstytucję Rzeczypospolitej Polskiej jako prawa podstawowe dla państwa oparte na poszanowaniu wolności i sprawiedliwości, współdziałaniu władz, dialogu społecznym oraz na zasadzie pomocniczości $(. . .)^{17}$.

Analizowana wartość pojawia się obok innych dóbr: wolności, współdziałania, dialogu i pomocniczości. Sąsiedztwo to profiluje pojęcie sprawiedliwości w kierunku rozumienia jej jako dobra w aspekcie polityczno-społecznym. Sprawiedliwość jest tu przedstawiona w charakterze podstawy systemu prawnego państwa, zaś jej usytuowanie w grupie wartości kolektywnych, związanych ze wspólnotą i solidarnością, podkreśla jej zbiorowy, ponadindywidualny wymiar. Analizowane dobro z założenia nie jest tym, które podlega partykularnym negocjacjom, nie może być akceptowane przez jednych, a ignorowane przez innych. W myśl ustawy zasadniczej dotyczy ono wszystkich, powinno być też wspólnie realizowane.

Ustrojodawca podkreśla, że sprawiedliwość pojmowana jako wartość stanowi podstawę praw, na których opiera się Rzeczpospolita. W art. 2 czytamy: Rzeczpospolita Polska jest demokratycznym państwem prawnym, urzeczywistniajacym zasady sprawiedliwości społecznej ${ }^{18}$. W przywołanym fragmencie pojawia się jeden z profili analizowanego pojęcia - sprawiedliwość społeczna ${ }^{19}$. Według

${ }^{13}$ Zob. J. Bartmiński, Kanon aksjologiczny jako narzędzie tożsamości grupowej, (w:) S. Niebrzegowska-Bartmińska, M. Nowosad-Bakalarczyk, S. Wasiuta (red.), Polskie wartości w europejskiej aksjosferze, Lublin 2014, s. 10-17.

${ }^{14}$ E. Malinowska, Konstytucja jako gatunek tekstu prawnego, Opole 2012, s. 81.

${ }^{15}$ Z. Stawrowski, Aksjologia i duch Konstytucji III Rzeczypospolitej, „Przegląd Sejmowy” 2004, nr 4, s. 55.

${ }^{16}$ Por. Z. Ziembiński, Wartości konstytucyjne, Warszawa 1993, s. 84.

${ }^{17}$ Konstytucja Rzeczypospolitej Polskiej z dnia 2 kwietnia 1997 r. ...

${ }^{18}$ Ibidem.

${ }^{19}$ Nazwa „sprawiedliwość społeczna” funkcjonuje jako termin prawny. Jego znaczenie podlegało zmianie pod wpływem rozwoju historycznego społeczeństw i praw. Sprawiedliwość społecz- 
Uniwersalnego słownika języka polskiego pod redakcją Stanisława Dubisza oznacza „przyznanie jednostce należnych jej praw zgodnie z zasadami demokracji” ${ }^{20}$. Może być rozumiana w kategoriach równości i równouprawnienia najważniejszych zasad ustroju demokratycznego. W kontekście egalitaryzmu sprawiedliwość społeczną można interpretować jako stosowanie bezstronnych kryteriów oceny czynów obywateli, równego (jednakowego) podziału dóbr, praw i obowiązków. Wskazany profil pojęcia sprawiedliwość wskazuje na jedną z najistotniejszych zasad w demokratycznej Polsce. Obok społecznej gospodarki rynkowej, demokracji związanej przede wszystkim z wolnością i równością oraz praworządności stanowi filar ideowy państwa ${ }^{21}$.

Inna perspektywa sprawiedliwości ujęta w ustawie zasadniczej wiąże się $\mathrm{z}$ aspektem prawnym. Artykuł 45 ust. 1 głosi, że każdy ma prawo do sprawiedliwego i jawnego rozpatrzenia sprawy ${ }^{22}$. W tym rozumieniu sprawiedliwość oznaczałaby „działanie zgodne z przyjętymi w państwie zasadami prawa i równe traktowanie obywateli podług tych zasad"23. Realizacji omawianej wartości obywatel Rzeczypospolitej powinien doświadczyć w interakcji z organami państwa, zwłaszcza związanymi z prawem i sądownictwem. Taką konotację wnoszą wyrażenia występujące zarówno w języku potocznym, jak i prawnym: wymiar sprawiedliwości i organy wymiaru sprawiedliwości. Sens przytoczonych kolokacji wskazuje, że podstawową funkcją instytucji sądowniczych jest działanie zgodne z zasadą sprawiedliwości i urzeczywistnianie tego dobra. Dbanie o praktyczny wymiar sprawiedliwości należy do zadań specjalnie powołanych organów państwa. Zgodnie z art. 175: Wymiar sprawiedliwości w Rzeczypospolitej Polskiej sprawuja Sąd Najwyższy, sądy powszechne, sąd administracyjny oraz sądy wojskowe ${ }^{24}$. Działalność tych organów nie ogranicza się do wymiaru sprawiedliwości pojmowanego jako ocena działań jednostek z perspektywy przyjętych norm prawnych, lecz rozszerza się także na troskę o aksjologiczny sens sprawiedliwości.

Pojęcie sprawiedliwości ujęte w Konstytucji Rzeczypospolitej z 1997 r. jest zaprezentowane wielowymiarowo. Ustrojodawca zawarł w ustawie zasadniczej następujące profile pojęcia sprawiedliwość: sprawiedliwość jako wartość uniwersalna, element uzupełniający klasyczną triadę wartości leżącą u podstaw europejskiego systemu aksjologicznego; sprawiedliwość społeczna pojmowana jako równość (jednakowość) praw, obowiązków i ocen dotyczących członków społeczeństwa; sprawiedliwość karna, czyli podleganie karze za czyny stojące

na odwołuje się do zasady równości - oznacza jednakowe traktowanie (uprawnienie) wszystkich członków społeczeństwa. Zob. hasło: sprawiedliwość społeczna w: Encyklopedia PWN, http://encyklopedia.pwn.pl/haslo/sprawiedliwosc-spoleczna;3978499.html (dostęp: 9.02.2019 r.).

${ }^{20}$ S. Dubisz (red.), Uniwersalny stownik języka polskiego, t. 3, Warszawa 2003.

${ }^{21}$ Zob. P. Sarnecki, Idee przewodnie Konstytucji Rzeczypospolitej Polskiej z 2 kwietnia 1997 roku, „Przegląd Sejmowy” 1997, nr 5, s. 15.

${ }^{22}$ Konstytucja Rzeczypospolitej Polskiej z dnia 2 kwietnia 1997 r. ...

${ }^{23}$ Objaśnienia nasze - I. Sz., E. G.

${ }^{24}$ Konstytucja Rzeczypospolitej Polskiej z dnia 2 kwietnia 1997 r. ... 
w sprzeczności z ustalonymi normami prawnymi. Konstytucyjne rozumienie nazwy sprawiedliwość do pewnego stopnia stanowi konkretyzację jej społecznego pojmowania, uwidocznionego w opisach leksykograficznych. W różnych słownikach języka polskiego ${ }^{25}$ hasło sprawiedliwość określane jest jako: „uczciwe, prawe postępowanie”, „obiektywizm”, „bezstronność”. Z rzadka podkreśla się w nich moralny sens sprawiedliwości - czyni to Halina Zgółkowa, która formułuje następującą charakterystykę sprawiedliwości: „wszystko, co jest zgodne z przyjętymi w danej społeczności zasadami etycznymi”" ${ }^{26}$.

\section{SPOLECZNE KONOTACJE SPRAWIEDLIWOŚCI ${ }^{27}$}

Ze względu na to, że odbiorcami Konsty tucji są nie tylko prawnicy, lecz także zwykli obywatele, pożądane byłoby przyjęcie takiej interpretacji pojęć w ustawie zasadniczej, która byłaby spójna $z$ ich potocznym rozumieniem ${ }^{28}$. Przedmiotem analizy w tej części artykułu są wypowiedzi potoczne dotyczące konotacji nazwy sprawiedliwość.

Konotacje społeczne badanego hasła zostały pozyskane w toku badania ankietowego przeprowadzonego w roku 2016 na grupie 300 studentów różnych uczelni i kierunków w Białymstoku, lecz białostoccy studenci pochodzą z różnych miejscowości regionu i kraju, a więc ich wypowiedzi można uznać za reprezentatywne dla młodszego pokolenia Polaków.

Tego, jak rozumiana jest nazwa sprawiedliwość i jakie konotacje potoczne jej towarzyszą, można dowiedzieć się z odpowiedzi na następujące pytania ankietowe: Jakie wartości sq ważne dla wszystkich ludzi?; Jakie wartości powinno

${ }^{25}$ Przywołane sensy słowa „sprawiedliwość” pochodzą z następujących publikacji: B. Dunaj (red.), Stownik współczesnego języka polskiego, t. 2, Warszawa 1999; S. Dubisz (red.), Uniwersalny słownik..., t. 3; H. Zgółkowa (red.), Praktyczny słownik współczesnej polszczyzny, t. 40, Poznań 2003.

${ }^{26}$ H. Zgółkowa (red.), Praktyczny słownik..., t. 40.

${ }^{27} \mathrm{Na}$ temat społecznych konotacji nazw wartości i zmiany sposobów rozumienia pojęć w dobie przemian ustrojowych zob.: J. Bartmiński (red.), Język-wartości - polityka. Zmiany rozumienia nazw wartości w okresie transformacji ustrojowej w Polsce. Raport z badań empirycznych, Lublin 2006. Hasło sprawiedliwość zostało w niej opracowane przez Irinę Lappo. Według badań przeprowadzonych przez lubelski zespół sprawiedliwość kojarzona jest głównie z równym traktowaniem ludzi (równością i równouprawnieniem) oraz z obiektywną oceną rzeczywistości. Narzędziami sprawiedliwości są natomiast prawo i sąd. Innymi konotacjami omawianego hasła są te dotyczące różnego rodzaju norm: prawnych, moralnych, społecznych (I. Lappo, Sprawiedliwość, (w:) Język-wartości-polityka..., s. 84-87).

${ }^{28}$ Zob. I. Szczepankowska, Polszczyzna prawna wobec wymagań komunikacyjnych wspótczesnego społeczeństwa, (w:) D. Kondratczyk-Przybylska, A. Niewiadomski, E. Walewska (red.), Jezyk polskiego prawa: nowe wyzwania, Warszawa 2016, s. 231. 
chronić państwo?; Jakie wartości sq cenione w twoim środowisku? oraz Jakie obiekty, zjawiska lub zachowania kojarza ci sie z takimi wartościami, jak sprawiedliwość ${ }^{29}$.

Wśród wartości uznanych przez respondentów za ważne dla wszystkich ludzi sprawiedliwość sytuuje się na 6. pozycji ${ }^{30}$ - wskazało ją 62 ankietowanych, co stanowi blisko $21 \%$ grupy badanych. Znalazła się ona, co prawda, na liście dóbr uznanych za ogólnoludzkie, lecz zyskała mniej niż jedną czwartą głosów młodych ludzi - nie jest to wynik podkreślający szczególną wagę tej wartości. Wyższą notę rankingową zyskuje ona w kontekście pytania o wartości, jakie powinno, zdaniem respondentów, chronić państwo - sprawiedliwość znajduje się na 4. pozycji ${ }^{31}$. Ten swoisty ,awans” nie ma jednak przełożenia na większą liczbę głosów wskazujących, że sprawiedliwość jest dobrem, które powinno być chronione prawem - opowiedziało się za tym 40 respondentów, co stanowi około $14 \%$ studentów biorących udział w badaniu. Być może wynika to ze sceptycznego podejścia młodych ludzi do ochrony sprawiedliwości przez władze - nie brakuje wydarzeń, nagłaśnianych przez media, obrazujących jawne i niejednokrotnie bezkarne sprzeniewierzanie się temu ideałowi. Sprawiedliwość znalazła się także wśród wartości cenionych w środowisku białostockich studentów - sytuuje się na 6. pozycji ${ }^{32} \mathrm{w}$ rankingu dzięki 46 głosom ankietowanych (15\% respondentów). Pozycja sprawiedliwości w tym obszarze jest bardzo zbliżona do miejsca tej wartości w hierarchii dóbr uznanych przez ankietowanych za ogólnoludzkie i tych, które ich zdaniem powinno chronić państwo. Przywołana statystyka obrazuje nie najwyższy stopień przekonania młodych Polaków o tym, że sprawiedliwość jest szczególnie istotną wartością, a jej ochrona jest warunkiem sine qua non poczucia bezpieczeństwa i ma kluczowe znaczenie dla ustroju demokratycznego.

Nazwa sprawiedliwość nasuwa pewne skojarzenia z osobami, postawami, instytucjami i innymi wartościami, które w opinii respondentów są odzwierciedleniem dobra przez nią denotowanego. W pojęciu dużej liczby badanych osób sprawiedliwość skorelowana jest z instytucjami, normami i osobami związa-

${ }^{29}$ Pytanie ankietowe: jakie obiekty, zjawiska lub zachowania kojarzq ci się z takimi wartościami, jak sprawiedliwość dotyczy następujących haseł: sprawiedliwość, prawda, dobro, piękno, wolność (swoboda), niepodległość (suwerenność), równość, (równouprawnienie), bezpieczeństwo, godność (dobre imię, cześć), moralność (sumienie), poczucie tożsamości.

${ }^{30}$ Wśród pierwszych dziesięciu haseł najczęściej pojawiających się w odpowiedzi na pytanie o wartości ogólnoludzkie pojawiły się: 1. miłość (107 powtórzeń), 2. rodzina (91), 3. wolność (86), 4. szczęście (85), 5. bezpieczeństwo (67), 6. sprawiedliwość (62), 7. zdrowie (55), 8. przyjaźń (47), 9. szacunek (38), 10. dobro (35).

${ }^{31}$ Ranking dziesięciu nazw najczęściej powtarzających się w tym kontekście jest następujący: bezpieczeństwo (95), wolność (88), rodzina (45), sprawiedliwość (40), równość (36), wolność słowa (19), godność (17), życie (15), niepodległość (13), pieniądze (11).

${ }^{32}$ Poza hasłem sprawiedliwość na liście dziesięciu najczęściej wskazywanych słów są: miłość (79), rodzina (73), szczęście (70), wolność (59), bezpieczeństwo (56), sprawiedliwość (46), przyjaźń (44), zdrowie (35), równość (32), prawda (28). 
nymi z prawem i sądem, czyli wymiarem sprawiedliwości. W tej grupie konotacji wskazanych przez respondentów znalazły się określenia instytucji: sąd (107 powtórzeń), Trybunat Konstytucyjny (2), więzienie (2). Zdaniem badanych instytucje te i osoby pełniące w nich służbę działają na rzecz ochrony sprawiedliwości i wspierają realizację tego dobra. Warto zauważyć, że sprawiedliwość kojarzy się studentom z karaniem za przewiny, co tłumaczy pojawienie się wśród konotacji leksemu więzienie i innych nazw powiązanych semantycznie z karaniem (te zostaną zaprezentowane $\mathrm{W}$ dalszej części analizy). W silnym związku z sądem i Trybunałem Konstytucyjnym są określone zdarzenia, charakterystyczne dla aktywności organów prawa, oraz ich efekty. Denotują je takie nazwy, jak: rozprawa (1), wyrok (3), kara (5). Wymienione leksemy nazywają główne elementy procedury sądowej. Poza alternatywnym wobec kary uniewinnieniem, zostały one przez respondentów wskazane jako kojarzące się ze sprawiedliwością i pomagające w stosowaniu jej w praktyce.

Swoistą alternatywą dla instytucjonalnego wyroku skazującego jest samosąd, czyli bezprawne ukaranie przez członków wspólnoty osoby uznanej za winną przestępstwa. Hasło samosąd pojawiło się w ankiecie trzykrotnie. Jego obecność jest świadectwem braku zaufania do instytucji sądu i konkretyzacją obaw o to, że osoba realnie bądź potencjalnie niebezpieczna może pozostać na wolności z mocy prawa.

Ostatnią grupą konotacji związanych z prawem i sądem są normy. Wypowiedzi ankietowanych dotyczą przede wszystkim prawa rozumianego jako zbiór przepisów. Ten aspekt sprawiedliwości ujęty jest w nazwie prawo (25) i synonimicznym określeniu przepisy (2). Respondenci wykazują legalistyczną postawę wobec omawianej wartości - o tym, co jest sprawiedliwe, decydują normy ustalone przez prawodawcę.

Ściśle związane z wymiarem sprawiedliwości są podmioty bezpośrednio odpowiedzialne za politykę państwa. Według studentów samo państwo, czyli swego rodzaju instytucja i struktura społeczno-polityczna, jest przestrzenią uobecniania się sprawiedliwości - takie skojarzenie pojawia się w 6 odpowiedziach. Intuicja ta jest zgodna ze stanowiskiem polskiego ustawodawcy. Zdaniem 4 respondentów organem decydującym o pojawieniu się poczucia sprawiedliwości wśród obywateli jest rząd - grupa polityków mających bezpośredni wpływ na obowiązujące normy prawne.

Inne skojarzenia ze sprawiedliwością dotyczą jednakowego traktowania ludzi - sprawiedliwie znaczy w tym przypadku tyle, co „po równo”. Na takie rozumienie pojęcia wskazują dwa hasła: równość (11) i równouprawnienie (7). Ten aspekt analizowanego dobra przypomina konstytucyjną sprawiedliwość społeczną, w której chodzi, ogólnie rzecz ujmując, o zrównanie obywateli w ich prawach i obowiązkach.

Sprawiedliwość w opinii studentów wiąże się z jeszcze inną wartością z prawdą (9). Prawda klasycznie rozumiana jako ,jedność myśli i słowa z rze- 
czywistością”33, „Zgodność tego, co się mówi, z tym, co jest” oraz „to, co istnieje obiektywnie"34 jest semantycznie bliska sprawiedliwości postrzeganej w kategoriach „obiektywności” i „bezstronności”. Na skorelowanie sprawiedliwości z prawdą wskazują dwa leksemy: denotujący wymiar komunikacyjny analizowanej wartości - prawdomówność (1) oraz wskazujący na sposób postępowania charakteryzujący się rzetelnością, szacunkiem, niezdolnością do oszustwa ${ }^{35}$ - uczciwość (1).

Interesujący zestaw konotacji stanowi ten odwołujący się do wymiaru sakralnego. Zawiera nazwę istoty duchowej - Bóg (11) oraz określenia duchowych pośmiertnych doświadczeń, stanowiących sakralny odpowiednik ziemskiego wymiaru sprawiedliwości - sad ostateczny (3), życie wieczne (1). W świetle przywołanych odpowiedzi ankietowych sprawiedliwość jawi się jako wartość o pochodzeniu transcendentnym, dobro wieczne, dane przez istotę najwyższą. Boska sprawiedliwość nie podlega redefinicji, zmianom, lecz jest kategorią stałą. Ujawni się w czasie sądu ostatecznego, czyli metafizycznego procesu osądzania ludzkich czynów. Interesujące jest wartościowanie, jakie towarzyszy decydowaniu o losie człowieka - negatywne w przypadku sądu ludzkiego: instytucjonalnego (kara) i pozainstytucjonalnego (samosą), pozytywne zaś w przypadku sądu Bożego (życie wieczne). Leksemami uzupełniającymi duchowy obraz sprawiedliwości są: nazwa instytucji - kościół (1), nazwa ogółu rytuałów, wierzeń, przekonań i systemu światopoglądowego - religia (1).

Warto odnotować obecność negatywnych opinii na temat sprawiedliwości. Niemała liczba respondentów uznała, że wartość ta jest nieobecna lub stała się dobrem niedostatecznie chronionym przez podmioty mające być jej ostoją. Sceptyczna postawa wobec sprawiedliwości konkretyzuje się w konotacjach: jest w zaniku (10), nie ma jej (3), na pewno nie w sadzie (1).

Przywołane konotacje społeczne w zdecydowanej większości są zbieżne z konstytucyjnym rozumieniem nazwy sprawiedliwość. Respondenci kojarzą denotowaną wartość głównie z wymiarem prawnym, politycznym i społecznym. Sytuują ją także wśród wartości ogólnoludzkich. Tym, co odróżnia potoczne skojarzenia z omawianą wartością od jej konstytucyjnych profili, jest skorelowanie jej ze sferą sakralną i zachowaniami międzyludzkimi, takimi jak uczciwość czy prawdomówność.

${ }^{33}$ Zdaniem Artystotelesa: „Powiedzieć, że istnieje o czymś, czego nie ma, jest fałszem. Powiedzieć o tym, co jest, że jest, a o tym, czego nie ma, że go nie ma, jest prawdą" - zob. J. Łukasiewicz, O zasadzie sprzeczności u Arystotelesa, Warszawa 1987, s. 18.

${ }^{34}$ H. Zgółkowa (red.), Praktyczny słownik..., t. 32, Poznań 2001.

${ }^{35}$ Zob. hasło: „uczciwość”, (w:) Słownik języka polskiego PWN, https://sjp.pwn.pl (dostęp: 10.02.2019 r.). 


\section{PODSUMOWANIE}

Na przestrzeni lat w polskim dyskursie konstytucyjnym pojęcie sprawiedliwość zyskiwało różne profile - w zależności od dominującego w danym czasie ustroju politycznego i światopoglądu. Wydaje się, że idea sprawiedliwości miała najmniejsze znaczenie w Konstytucji 3 Maja z 1791 roku (ze względu na pilną potrzebę ochrony innych dóbr - niepodległości państwa i wolności narodu) oraz w Konstytucji Polskiej Rzeczypospolitej Ludowej (z 1952 roku), w której usankcjonowano przede wszystkim wartości ściśle społeczne. Sprawiedliwość zyskała na znaczeniu w Konstytucji Rzeczypospolitej Polskiej z 1997 roku. W aktualnej ustawie zasadniczej usytuowano tę wartość wśród Platońskich idei uniwersalnych (dobra, prawdy i piękna); uznaje się ją także za zasadę polskiej demokracji.

Nazwa sprawiedliwość zyskiwała w polskich konstytucjach różnorodne sensy odpowiadające stanowi świadomości społecznej i politycznej rządzących. W systemie feudalnym sprawiedliwość rozumiana jako „równouprawnienie”, „równe traktowanie przez władcę" odnosiła się wyłącznie do przedstawicieli określonego stanu. Miara tej wartości była różna - w zależności od społecznej przynależności podwładnych. Z czasem pojęcie sprawiedliwości rozszerzyło się na wszystkich mieszkańców danego kraju i do dziś kojarzy się z powszechną równością wobec prawa państwowego i norm społecznych. W rozumieniu pojęcia zaznacza się ewolucja wartości: od ekskluzywnej dostępności dla nielicznych do pluralizmu obejmującego wszystkich.

W toku rozwoju historycznego sprawiedliwość zyskiwała różne profile znaczeniowe. Kojarzyła się przede wszystkim z prawem w rozumieniu podmiotowym (słuszne uprawnienie) oraz przedmiotowym (zgodność z prawem), a także z instancjami wymiaru sprawiedliwości (sprawiedliwy sąd) i karą (sprawiedliwy wyrok). Ten aspekt semantyki analizowanej nazwy jest silnie obecny w języku do dziś. Poza sensem prawnym sprawiedliwość konotuje także „równość”, czyli „jednakowe traktowanie wszystkich ludzi”, w tym „równość wobec prawa”, „obiektywność wyroku sądowego" (równouprawnienie). Z czasem sprawiedliwość zyskuje także walor społeczno-polityczny, który znajduje odzwierciedlenie w ideale sprawiedliwości społecznej rozumianej jako „zrównanie szans wszystkich obywateli i jednakowe ich ocenianie" - ten aspekt jest wyraźnie podkreślony w Konstytucji RP z 1997 roku. W niej także pisze się o sprawiedliwości jako idei aksjologicznej, abstrakcyjnej wartości uniwersalnej leżącej u podstaw systemu wartości polskiego narodu, traktowanej jako naczelna zasada moralna i ustrojowa Rzeczypospolitej.

W oczach młodych Polaków sprawiedliwość jawi się jako wartość ogólnoludzka, ważna w ich środowisku oraz taka, którą powinno chronić państwo. Można by się jednak spodziewać większego, niż wykazało badanie ankietowe, umocowania sprawiedliwości w systemie wartości respondentów. Choć spra- 
wiedliwość jest stałym elementem ich obrazu świata, to nie zyskuje wysokiego miejsca w hierarchii cenionych dóbr. Konotacje społeczne oscylują, podobnie jak znaczenia konstytucyjne, wokół rozumienia prawnego (sprawiedliwe są: prawo, sąd, kara itp.) i skorelowanego z nim ujęcia w kategoriach równościowych (równość, równouprawnienie). Respondenci wskazali także podmioty państwowe, które ich zdaniem powinny troszczyć się o ochronę sprawiedliwości - są nimi państwo i rząd (rządzący). Podobnie jak czyni to obecny ustrojodawca, respondenci kojarzą sprawiedliwość $\mathrm{z}$ wartością uniwersalną, jaką jest prawda. W badaniu ujawniły się także pewne konotacje społeczne związane $\mathrm{z}$ określonymi postawami wobec osób z otoczenia (prawdomównością, uczciwością). Interesujące w pojmowaniu sprawiedliwości przez studentów - w porównaniu z jej rozumieniem w polskim dyskursie konstytucyjnym - jest skorelowanie tego dobra ze sferą sakralną: z Bogiem, życiem wiecznym i sądem ostatecznym.

\section{BIBLIOGRAFIA}

\section{Literatura}

Bartmiński J. (red.), Język - wartości - polityka. Zmiany rozumienia nazw wartości $w$ okresie transformacji ustrojowej w Polsce. Raport z badań empirycznych, Lublin 2006

Bartmiński J., Kanon aksjologiczny jako narzędzie tożsamości grupowej, (w:) S. Niebrzegowska-Bartmińska, M. Nowosad-Bakalarczyk, S. Wasiuta (red.), Polskie wartości w europejskiej aksjosferze, Lublin 2014

Boryś W., Stownik etymologiczny języka polskiego, Kraków 2005

Dubisz S. (red.), Uniwersalny słownik języka polskiego, t. 3, Warszawa 2003

Dunaj B. (red.), Stownik wspótczesnego języka polskiego, t. 2, Warszawa 1999

Konstytucja 3 Maja 1791. Statut Zgromadzenia Przyjaciół Konstytucji, oprac. J. Kowecki, Warszawa 1991

Lappo I., Sprawiedliwość, (w:) Język - wartości - polityka. Zmiany rozumienia nazw wartości w okresie transformacji ustrojowej w Polsce. Raport z badań empirycznych, Lublin 2006

Linde S. B., Stownik języka polskiego, t. 1-7, Lwów 1854

Litewski W., Słownik encyklopedyczny prawa rzymskiego, Kraków 1998

Łukasiewicz J., O zasadzie sprzeczności u Arystotelesa, Warszawa 1987

Malinowska E., Konstytucja jako gatunek tekstu prawnego, Opole 2012

Puzynina J., Język wartości, Warszawa 1992

Sarnecki P., Idee przewodnie Konstytucji Rzeczypospolitej Polskiej z 2 kwietnia 1997 roku, „Przegląd Sejmowy” 1997, nr 5

Stawrowski Z., Aksjologia i duch Konstytucji III Rzeczypospolitej, „Przegląd Sejmowy” 2004, nr 4

Szczepankowska I., Polszczyzna prawna wobec wymagań komunikacyjnych wspótczesnego społeczeństwa, (w:) D. Kondratczyk-Przybylska, A. Niewiadomski, E. Walewska (red.), Język polskiego prawa: nowe wyzwania, Warszawa 2016 
Szczepankowska I., Prawo $i$ wolność $w$ dyskursie politycznym Rzeczypospolitej przedrozbiorowej (podstawowe problemy badawcze), „Poradnik Językowy” 2008, nr 8

Szczepankowska I., Zwiazki polskiego, amerykańskiego i francuskiego dyskursu konstytucyjnego w XVIII wieku, (w:) Dyskurs prawny. Języki, teksty i konteksty, Białystok 2016

Zgółkowa H. (red.), Praktyczny słownik wspótczesnej polszczyzny, t. 32, Poznań 2001

Zgółkowa H. (red.), Praktyczny stownik współczesnej polszczyzny, t. 40, Poznań 2003

Ziembiński Z., Wartości konstytucyjne, Warszawa 1993

\section{Strony internetowe}

Encyklopedia PWN, http://encyklopedia.pwn.pl/ (dostęp: 9.02.2019 r.)

Słownik języka polskiego PWN, https://sjp.pwn.pl (dostęp: 10.02.2019 r.)

Stawrowski Z., Aksjologiczne podstawy Konstytucji, Rzecznik Praw Obywatelskich, http://www.rpo.gov.pl/pliki/12180269390.pdf (dostęp: 3.02.2019 r.)

\section{Inne źródła}

Konstytucja Polskiej Rzeczypospolitej Ludowej z dnia 22 lipca 1952 r., Dz.U. nr 33, poz. 232

Konstytucja Rzeczypospolitej Polskiej z dnia 2 kwietnia 1997 r., Dz.U. nr 78, poz. 483, z późn. zm.

Ustawa z dnia 17 marca 1921 r. - Konstytucja Rzeczypospolitej Polskiej, Dz.U. nr 44, poz. 267

\section{JUSTICE IN THE POLISH CONSTITUTIONAL DISCOURSE AND ITS SOCIAL CONNOTATIONS}

\section{Summary}

The analysis of the use of the notion of justice in the Polish Constitution proves that in the course of historical development, the designated value was given various conceptual profiles. It was associated mostly with the law within the subjective ('justified entitlement') and objective scope ('legitimacy'), with the judicial authorities ('fair hearing'), and with the punishment ('just decision'). Apart from juridical meaning, the notion of justice shall connote 'equality' or 'equal treatment of all people', including 'equal justice under law' or 'objectivity of a judicial ruling'. Over time the justice gains social and political value which is reflected in the ideal of social justice meant as 'the equality of all citizens and equal evaluation thereof'. The latter is highlighted in the Polish Constitution (of 1997) where justice is treated as the guiding moral and constitutional principle in the Republic of Poland. The significant profiles of names designating justice in the texts of the Constitution are confronted with the connotations appearing in the questionnaires filled up by the students of the universities in Białystok. In the eyes of 
young Poles, justice seems to be a human value which is important in their environment an shall be protected by the state.

\section{KEYWORDS}

polish constitutional discourse, justice, names of values, connotations

\section{SŁOWA KLUCZOWE}

polski dyskurs konstytucyjny, sprawiedliwość, nazwy wartości, konotacje 